\title{
BENJAMIN'S CONCEPTION OF LANGUAGE AND ADORNO'S AESTHETIC THEORY
}

\author{
Rodrigo Duarte* \\ roduarte@uai.com.br
}

RESUMO De acordo com a teoria da linguagem do jovem Benjamin, a tarefa primordial da linguagem não é a comunicação de Conteúdos, mas expressar a si própria como uma "essência espiritual", da qual também o gênero humano toma parte. Essa concepção, de acordo com a qual a linguagem seria um médium para a significação de algo fora dela leva necessariamente a uma diminuição de sua potência originária e é, portanto, chamada por Benjamin burguesa (bürgerlich). Os nomes da linguagem humana são resquícios de um estado arcaico, no qual as coisas ainda não eram mudas e tinham sua própria linguagem. Benjamin sugere também que todas as artes rememoram a linguagem originária das coisas, na medida em que fazem os objetos "falarem" em forma de sons, cores, formas etc. Essa relação entre arte como resquício da "linguagem das coisas" e a possível reconciliação do gênero humano consigo próprio e com a natureza foram desenvolvidas por Theodor Adorno em vários de seus escritos, especialmente na Teoria Estética, onde a obra de arte é concebida, em última análise, como permeada de "linguagem" no seu significado mais amplo, não no sentido "burguês".

Palavras-chave Teoria Crítica da Sociedade, Escola de Frankfurt, Linguagem das Coisas

ABSTRACT According to the theory of language of the young Benjamin, the primary task of language isn't the communication of contents, but to express

* Professor do Departamento de Filosofia da UFMG. Artigo recebido em 15/09/05 e aprovado em 15/11/05.

KRITERION, Belo Horizonte, n $^{\circ}$ 112, Dez/2005, p. 321-331 
itself as a "spiritual essence" in which also men take part. That conception according to which language would be a medium to signification of something outside it leads to a necessary decrease of its original strength and is thus denominated by Benjamin bürgerlich. The names of human language are remainders of an archaic state, in which things weren't yet mute and had their own language. Benjamin suggests also that all the arts remind the original language of things, as they make objects "speak" in form of sounds, colors, shapes etc. That relationship between arts as reminders of the "language of things" and the possible reconciliation of mankind with itself and with nature has been developed by Theodor Adorno in several of his writings, specially in the Aesthetic Theory, where the artwork is ultimately conceived as a construct pervaded by "language" in the widest meaning - not in the "bourgeois" sense.

Keywords Critical Theory of Society, Frankfurt School, Language of Things

In his text of 1916, "On Language as Such and on the Language of Man", Walter Benjamin developed some ideas on language that have not only oriented many of his own later approaches to art, culture and society, but also strongly influenced other thinkers of the philosophical current known as the "Frankfurt School". The main difference between Benjamin's conception and the conventional theories of language is that language for him communicates nothing but the mental entity of things and, very particularly, the mental being of men (das geistige Wesen des Menschen). It means that the part of language concerning human beings cannot be conceived as a means of communication among men, but rather as a medium in which (not through which) the mental being of men expresses itself. For Benjamin the former would necessarily lead to what he calls "bourgeois conception",, in which language is abused regarded only as a means to enable the communication of men.

According to what Benjamin calls "purified conception" (LSM 123), the language of man has the privilege to give things their names. Naming is the essence of human language as an echo of the creative activity of God's word. While creating things, God provided each of them with a sign, endowing men, nevertheless, with a language based on names - a type of sign that summarizes language as the mental being of men (as Benjamin says: "language of language") — so that creation could be completed by the naming skill of men. The naming

1 On Language as Such and on Language of Man. In: One-Way Street and Other Writings. Translated by Edmund Jephcott and Kingsley Shorter. London: NBL, 1979. p. 111. It will be designated here by "LSM" followed by the page number. 
capability of men's language makes it much more perfect than the language of things, since the latter is soundless, and communicates to men its mental being through mute signs inserted in them by God. Through the naming activity of man, his mental being communicates itself to God, while he establishes a relationship of knowledge to things, understood as a translation of their dumb language into man's sonorous name-language. Among the superior types of language-beings, the proper name is described by Benjamin as the middle term between God's word and the names of human language; in his own expression, "the communion of man with the creative word of God" (LSM 116).

The state of things described above was for the philosopher a paradisiacal one, i.e., prior to the Fall. After the Fall, language of man is no longer based only on names, but embodies also nameless judgements driven by ordinary signs, what leads to an endless "prattle" dominated by abstraction and culminating in a kind of "overnaming" (LSM 120-1), which on one hand originated the multiplicity of languages we have today and on the other hand caused an "excess" of signification of each thing, disturbing the more perfect knowledge achieved before. Such excess of signification consummates the birth of the aforementioned "bourgeois conception of language", i.e. language as a mere means of communication.

A particularly interesting consequence of the Fall, concerning language, is that Nature's suffering under its overnaming led it to a second, "other muteness" (LSM 121) which is no longer blissful like the original, that was given by God himself, but is deeply sad and bitter. It is a silent mourning of Nature for the loss of immediacy in the communication of its mental being to men.

This conception of a "second muteness" of nature leads to a Benjaminian insight into the potential of art to overcome the kind of alienation brought on by the original sin: it concerns the establishment of a close relationship between the mute language of things and the several kinds of artwork, so that their nonverbal expression is supposed to be a reflection of the former (language of things) on the latter (the arts). Quoting:

There is a language of sculpture, of painting, of poetry. Just as the language of poetry is partly, if not solely, founded on the name language of man, it is very conceivable that the language of sculpture or painting is founded on certain kinds of thing languages, that in them we find a translation of the language of things into an infinitely higher language, which may still be of the same sphere. We are concerned here with nameless, nonacoustic languages, languages issuing from matter; here we should recall the material community of things in their communication (LSM122). 
The situation, pointed out by Benjamin, concerning the "language of things" can be visualized in the following scheme:

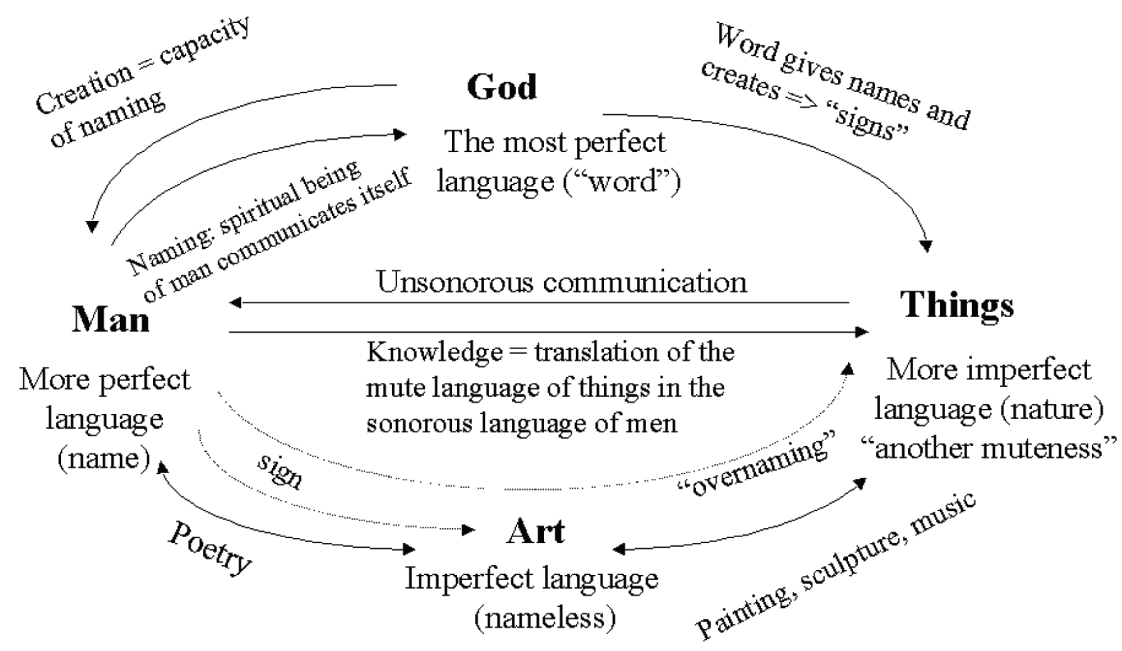

Unfortunately Benjamin's standpoint concerning the relationship between art in general and the language of things was not explicitly and fully developed by him. Neither in the text we now analyze, nor elsewhere, although, as pointed before, some other conceptions of it have oriented many of his own later approaches to art, culture and society and were taken up in other writings as "The Task of the Translator" ${ }^{2}$ and the theory of knowledge presented in the preface to Origin of German Tragic Drama. ${ }^{3}$

As a kind of complement to the theory of language exposed in the 1916 paper I would like to comment on some aspects of the theory of translation exposed in "The Task of the Translator". Here again it is presupposed that there is a higher language associated with divinity soaring above the several human languages. If in Benjamin's early writing translation is defined as the "removal of one language into another through a continuum of transformations" (LSM 117), it expresses now an inner relationship of languages among

2 In: Illuminations. Edited by Hannah Arendt, translated by Harry Zohn. New York: Harcourt, Brace \& World Inc., 1968. p. 69-82.

3 Ursprung des deutschen Trauerspiels. Frankfurt (Main): Suhrkamp, 1978. The Origin of German Tragic Drama. Verso: London/New York, 1985. Translated by J ohn O sborne. There is an "echo" of the language-ofthings-theory in the second part of the chapter "Allegory and Tragic Drama", but Benjamin didn't use this term in it. 
themselves, so that what lacks in one, when compared with the higher language, is supposed to be found in another.

Furthermore, just like knowledge in general cannot be understood as a copy (Abbild) of its object, the quality of translation, according to Benjamin, cannot be measured by its fidelity to the original work also due to the fact that the language of the original as well as that of the translation don't remain the same themselves, which makes impossible a permanent similarity between them. But their reference to the "pure language" is always the same since this is not subject to the modifications taking place under influence of historical movements. Quoting:

Rather, all suprahistorical kinship of languages rests in the intention underlying each language as a whole - an intention, however, which no single language can attain by itself but which is realized only by the totality of their intentions supplementing each other: pure language. While all individual elements of foreign languages - words, sentences, structure - are mutually exclusive, these languages supplement one another in their intentions ${ }^{4}$.

Taking this into account, it is not the similarity of a translation to its original that would be the most important, but what Benjamin calls the "mode of intention" (Art des Meinens) of the several languages which complete each other, so that the perfect translation should find out which "mode of intention" is the real "complementary" of the one presented in the original in relation to the highest language. This language contains per definitionem an harmony of the "mode of intention" of all separate languages and their correct translation, relating the language into which it is translated and the one from which it is translated to pure language, which contributes to their survival until the time of their redemption in the messianic end of history, in which there would be no longer distinction between the pure language and the empirical ones.

It is also interesting to mention that although many important poets were (and are) very good translators (like Hölderlin, Schlegel, Georg, etc.), Benjamin sees translation as a form per se, so that one can distinguish very clearly the task of the translator from that of the poet. While the former consists in finding that intention of the language into which it is translated, in which the echo of the original is awaken, the latter intends language not as a whole, but in some specific relations of contents (Gehaltszusammenhänge). However, in "The Task of the Translator" as in the text on "Language as such...", both forms translation and poetry — are not supposed to communicate anything but to

4 In: Illuminations, op. cit., p. 74. 
establish a relationship to language in general, which corresponds to the "communication of the mental being" in the earlier text.

In "The Task of the Translator" Benjamin sees in translation a seed of "pure language" that is supposed to be "inside" the foreign one (the language from which something is translated) and this seed must be saved by the translator for his own language. Benjamin exemplifies this with the tangent and the circle: the former touches the latter only at one point, which is already enough to define the law of tangency. The point the translation must touch is that of the sense of the original, so that it can follow its way according to the law of fidelity but with the language's liberty of movement (Sprachbewegung).

As for the preface of the Origin of German Tragic Drama, there can be noticed a lot of similarities to the 1916 text on language, such as the distinction between knowledge and truth implicit in his conception of tractate. While knowledge and its operational units - the concepts - concern a kind of ownership of something in conscience which endeavors the "salvation of phenomena", truth consists in the presentation (Darstellung) of ideas - Platonic ideas understood here as "origins" - conceived as free of any intention, in the same way the realm of pure language itself is supposed to be. Differently from the writing on "Language as such", where "idea" is defined as a being lacking any relationship to language (LSM 108), the preface to the Origin of German Tragic Drama points to the belonging of ideas among the more general references of language: "The idea is something linguistic, it is that element of the symbolic in the essence of any word". 5

The most evident relationship between both texts, besides the sacred character attributed to names, is the resemblance of the realm of pure language to the Platonic world of ideas, which Benjamin describes as a domain in which the empirical language has no influence at all. He also designates in Origin of German Baroque Drama the "world of ideas" as a paradisiacal one, so that, according to him, it would be more correct to consider Adam than Plato the founder of philosophy, since the former was the first to give name to things:

Adam's action of naming things is so far removed from play or caprice that it actually confirms the state of paradise as a state in which there is no need to struggle with the communicative significance of words. Ideas are displayed, without intention, in the act of naming, and they have to be renewed in philosophical contemplation. ${ }^{6}$

5 Ursprung..., op. cit., p. 18; Origin..., op. cit., p. 36.

6 Origin..., op. cit., p. 37. 
Before I point out the way in which Adorno understood and tried to develop the Benjaminian insight on the relationship between language of things and artworks, I would like to mention something about its influence on Adorno and Horkheimer's common book Dialectic of Enlightenment, today considered as one of the founding works of the "Critical Theory of Society". Despite its evident non-theological approach, this work adopts the Benjaminian thesis of an originary word that undergoes fragmentation through History and results in Western positivistic science with its utilitarian conception of language apart from the various art branches. Quoting:

With the clean separation of science and poetry, the division of labor it had already helped to effect was extended to language. For science the word is a sign: as sound, image, and word proper it is distributed among the different arts, and is not permitted (permitted) to reconstitute itself by their addition, by synaesthesia, or in the composition of the Gesamtkunstwerk. As a system of signs, language is required to resign itself to calculation in order to know nature, and must discard the claim to be like her. ${ }^{7}$

Nevertheless, the influence of Benjamin's point of view didn't limit itself to the common work of both philosophers, appearing likewise in several passages of their individual writings. We see, for instance, Horkheimer recalling the relationship between art and language of things in his Eclipse of Reason as an index of our present reification in so an eloquent way as following: "Once it was the endeavor of art, literature, and philosophy to express the meaning of things and of life, to be the voice of all that is dumb, to endow nature with an organ for making known her sufferings, or, we might say, to call reality by its rightful name. Today nature's tongue is taken away". 8

Adorno's work is so much permeated of references to Benjamin's theory of language that it would be impossible to quote or even to indicate all of them. Nevertheless, there is a passage already in his Minima Moralia where he explicitly mentions it, pointing out the relationship of music to the language of things. Quoting: "Just as, according to Benjamin, painting and sculpture translate the mute language of things into a higher but similar one, so it might be supposed that music rescues name as pure sound — but at the cost of severing it from things". ${ }^{\circ}$

This standpoint of Adorno's in relation to music was developed in several other writings in the fifties and sixties, as "Fragment about Music and

7 Dialectic of Enlightenment. Translated by John Cumming. New York: Continuum, 1996. p. 17-18.

8 Eclipse of Reason. New York: Continuum, 1974. p. 101.

9 Translated by E. F. N. Jephcott. London: Verso Editions, 1987. p. 222-223. 
Language" (1956) and "On the Relationship of Painting and Music Today"10. It is true that points of view concerning partial aspects of the relationship between pure language and the fine arts have already appeared, among others, in "The Task of the Translator" and Origin of German Baroque Drama. It occurs in Benjamin also - as, for instance, in the Preface to this work while commenting Plato's Symposium - more general aesthetic questions, like the establishment of a connection between truth and beauty. In both cases, however, there isn't a development of the insight concerning art as a whole and the language of things, but only approaches to forms of expression more closely related to the "language of men".

In this sense it could be very helpful to inquire about the relationship between the types of art closer to material objects and the "language of things" in a similar way to what Adorno does in his approaches on the conception of art as language extended to all other artistic branches, mainly in Aesthetic Theory. This posthumous book of Adorno's is a vigorous attempt to connect the main thesis of the Dialectic of Enlightenment to his experiences with culture in the "administered world" (verwaltete Welt) putting special emphasis on the difficult situation of autonomous art in a scene almost totally dominated by "culture industry" - the most extreme instance of instrumentalization of mental expression. This is the background where the influence of Benjamin's approach to language can be felt either in a general or in more specific sense. The following passage is an example of this influence in a general way: "Art would like, with human means, to achieve the speech of what is not human. (...) If the language of nature is mute, art seeks to make this muteness eloquent". ${ }^{11}$

There are, nevertheless, more specific points of contact between Benjamin's early conception of language and Adorno's late work Aesthetic Theory, of which I would like to mention two closely related aspects: 1 . the "thing-character" of artwork and 2. the capacity of it to speak voicelessly, so representing the mute nature.

For Benjamin it is typical of every language a kind of relationship from what is speakable to what is pure and simply unspeakable, the latter being something that would be known only through "revelation", not by means of human capacities. According to Adorno's secularized point of view, artworks originate by means of a crystallization of many forces acting inside them in a sort of thing (Ding), without which they wouldn't deserve the designation of

10 Gesammelte Schriften. Frankfurt (Main): Suhrkamp, 1984. Respectively v. 16, p. 251, and v. 18, p. 142.

11 Ästhetische Theorie. Frankfurt (Main): Surhkamp, 1986. p. 121; Aesthetic Theory. Translated by Robert Hullot-Kentor. London: Athlone Press, 1997. p. 78. Passages quoted here will be designated by "AT" followed by the page number. 
artworks and through which they reach a kind of unsonorous language like the one atributed to nature by Benjamin. The Aesthetic Theory gives some intimation of this: "The mimetic impulses that motivate the artwork, that integrate themselves in it and once again disintegrate it, are fragile, speechless expression. They only become language through their objectivation as art. Art, the rescue of nature, revolts against nature's transitoriness". (AT, 184) The idea of artwork becoming a "thing", as a result of an internal dialectic process, is reinforced by the claim of its - once a ready construct — becoming something essentially independent of its creator. Quoting once more from Aesthetic Theory:

The emancipation of the artwork from the artist is no l'art pour l'art delusion of gradeur but the simplest expression of the work's constitution as the expression of a social relation that bears in itself the law of its own reification: Only as things do artworks become the antithesis of the reified monstrosity (AT, 167)

Adorno's statement clearly indicates the necessity of what he calls "objectification" (Vergegenständlichung) of artworks — an emphasis on their material basis in which an intellectual content is mixed up - in order to face reification, understood as the reduction of men to the condition of thing. In other words, the attribution of a spiritual significance to a thing, as the artist does in his creative activity, helps to understand the process whose result is the transformation of essentially mental beings into mere things. Adorno connects the present state of almost general alienation of individuals with oppressed nature in a similar way to Benjamin's association of the second muteness of nature and the abuse of language for pragmatic purposes. To the idea, originally coming from Benjamin of art as a remembrance of things' language, Adorno adds the suggestion that the respectively most modern art is the best way to achieve that reminiscence:

\footnotetext{
Radicalized, what is called reification probes for the language of things. It narrows the distance to the idea of that nature that extirpates the primacy of human meaning. Emphatically modern art breaks out of the sphere of the portrayal of emotions and is transformed into the expression of what no significative language can achieve. Paul Klee's work is probably the best evidence of this from the recent past, and he was a member of the technologically minded Bauhaus. (AT, 60)
}

Another typical trace of Adorno's approach to the relationship between art and the language of things is its correlation with his theory about "nature's beauty" (Naturschöne). This constitutes a very central part of Aesthetic Theory, in which Adorno discusses Kant's favorable position concerning nature's beauty in the Critique of Judgement and its critique by Hegel in his Aesthetics. While 
for Kant the "taste judgement" (Geschmacksurteil), with its "satisfaction without interest", is best fulfilled when referred to natural objects, that also present a "moral superiority" in comparison to artistic beauty, ${ }^{12}$ for Hegel natural beauty is totally unsubstantial, since it depends not on the quality of the object to be evaluated, but on a disposition of the person who perceives the natural phenomenon. ${ }^{13}$ If Adorno, on one hand, recognizes the importance of Kant's position in an age in which nature is being systematically destroyed, he, on the other hand, is aware of its anachronism. Now, Hegel's pure and simple rejection of nature's beauty in itself seems, in its optimism about the course of the absolute idea, to ignore the dangers of our present situation. Here the Benjaminian insight into the relationship between mute nature and expression of art assumes a very decisive role, inasmuch as for Adorno the kind of art that makes no concession to its general understanding, focusing mainly the artistic expression in itself, can achieve the capacity of representing the oppressed nature to the extent it succeeds in emulating its beauty:

This dignity has been transformed into the hermetic character of art, into - as Holderlin taught - art's renunciation of any usefulness whatever, even if it were sublimated by the addition of human meaning. For communication is the adaptation of spirit to utility, with the result that spirit is made one commodity among the rest; and what today is called meaning participates in this disaster. What in artworks is structured, gapless, resting in itself, is an after-image of the silence that is the single medium through which nature speaks. Vis-à-vis a ruling principle, vis-à-vis a merely diffuse juxtaposition, the beauty of nature is an other; what is reconciled would resemble it. (AT, 74)

In the critique of communication showed above one can clearly hear an echo of Benjamin's critique to the "bourgeois conception" of language, just as the eloquent silence of nature remembers its "second muteness" pointed in the text of 1916. This critique of communication shows a close relationship with another important point of Kant's Aesthetics: the "purposiveness without purpose" (Zweckmäßigkeit ohne Zweck), which means the complementary aspect — on the side of the object to be considered beautiful — to the "pleasure without interest" typical of taste judgement in its Kantian version. The object intimates to be adjusted to some purpose without making this purpose explicit ${ }^{14}$ thus suggesting the very peculiar situation of a beautiful thing — a thing whose

12 Kritik der Urteilskraft. Frankfurt (M), Suhrkamp, 1986. The traces of taste judgemente can be found in the paragraphs 1 to 10 of the "Analitic of Beauty". The precedence of natural objects in the taste judgement is in paragraphs 14 to 16 and the moral superiority os nature's beauty can be found in paragraph 42 .

13 Vorlesungen über die Ästhetik I. Frankfurt (Main): Suhrkamp, 1983. p. 13 and 166.

14 Kritik der Urteilskraft, op. cit., paragraphs 9 to 11. 
utility is not so clear - in a world, already in the time of Kant, dominated by a kind of dictatorship of usefulness. In Adorno's attempt to translate the Kantian position into more up-to-date terms is once more noticeable the influence of Benjamin's conception of "language of things", namely on the connection between "adjustment to purposes without purpose" and the language of artworks, which should get nearer to that of the things:

Artworks move toward the idea of a language of things only by way of their own language, through the organization of their disparate elements; the more they are syntactically articulated in themselves, the more eloquent they become in all their elements. The aesthetic concept of teleology has its objectivity in the language of art. (AT, 140)

Besides the undeniable weight of Benjamin's point of view it could be considered as Adorno's own contributions not only the emphasis with which he insists on the necessity of stylistic modernity for artworks in order that they take in the representativeness of nature's beauty, but also a new definition of mimesis: the traditional conception of art as imitation of nature. Even considering that this conception has been submitted to a severe critique since the 18th century, Adorno can be considered responsible for an important shift as he declares that "Art does not imitate nature, not even individual instances of natural beauty, but natural beauty as such" (AT, 72). Although this point cannot be fully developed for reasons of economy of my exposition, I expect to have at least indicated the way in which there can be established a relationship between Benjamin's idea of art as an emanation of the language of things and Adorno's theory about nature's beauty - a standpoint of his which shows a great potential for the critical evaluation of culture today.

And if we have in mind that everyone today is subject to something like a "bombing" of images, sounds and words, which, far from approaching what Benjamin called "language of things", is more related to the "overnaming" of the "bourgeois conception of language", the importance of that critical evaluation imposes itself with all the more emphasis. Also, it can be remembered that the phenomenon of "culture industry", analyzed by Adorno and Horkheimer in the forties - in the Dialectic of Enlightenment ${ }^{15}$ — as something concerning local spheres of influence, has since that time spread to an universal issue, accentuated by the rise of what is called today "globalization". ${ }^{16}$

15 In the chapter "The Culture Industry. Enlightenment as Mass Deception”, op. cit., p. 120-167.

16 About the changes in the conception of culture industry concerned to the rise of "globalization", see my article: "Zurück in die Zukunft. Die kritische Theorie der Kulturindustrie und die 'Globalisierung"'. Zeitschrift für kritische Theorie, n. 10, p. 61-71, 2000. 